Supporting Information

\title{
Layered double hydroxide quantum dots for use in bifunctional separator of lithium sulfur batteries
}

Qing Liu, ${ }^{\dagger,+, \#}$ Xiaotong Han, ${ }^{\dagger, \#}$ Hyunyoung Park, ${ }^{\S}$ Jongsoon Kim, ${ }^{\S}$ Peixun Xiong, ${ }^{\dagger}$

Haocheng Yuan,,$^{\dagger}$ Jeong Seok Yeon, ${ }^{\dagger}$ Yingbo Kang,,$^{\dagger}$ Jae Min Park, ${ }^{\dagger}$ Qingyun Dou,,$^{\dagger}$

Bo-Kyong Kim,,$\stackrel{*}{+}$ and Ho Seok Park ${ }^{*}, \dot{\dagger}$

${ }^{\dagger}$ School of Chemical Engineering, Department of Health Sciences and Technology,

Samsung Advanced Institute for Health Sciences and Technology (SAIHST), and

SKKU Advanced Institute of Nano Technology (SAINT), Sungkyunkwan University,

Suwon 440-746, Republic of Korea

${ }^{*}$ Smart Electrical \& Signaling Division, Intermodal Transfer System Research Team, Korea Railroad Research Institute, Republic of Korea

${ }^{\S}$ Department of Energy Science, Sungkyunkwan University, 2066, Seobu-ro, Jangangu, Suwon-si, Gyeonggi-do 440-746, Republic of Korea

${ }^{\#}$ These authors contributed equally to this work.

E-mail:

${ }^{8}$ Corresponding author: bkkim@krri.re.kr (B.-K. Kim)

†Corresponding author: phs0727@skku.edu (H. S. Park) 


\section{Experimental Section}

\section{Preparation of MWCNT/S cathode}

Using a typical synthesis, the active material was prepared by mixing multi-walled carbon nanotubes (MWCNTs) with commercial sulfur at a mass ratio of 4:1 through a milling process. The mixture was then transferred into a sealed Teflon bottle filled with Ar gas and heated at $155^{\circ} \mathrm{C}$ for $9 \mathrm{~h}$ to melt the sulfur into the porous MWCNT (S content of $\sim 77 \%$, see Figure S12). The sulfur cathode was prepared by coating a slurry containing the active material, carbon black, and PVDF at a weight ratio of 7:2:1 on aluminum foil and punched into disks with a diameter of $12 \mathrm{~mm}$. The mass loading is $\sim 1.2 \mathrm{mg} \mathrm{cm}^{-2}$.

\section{Material characterization}

The prepared materials were analyzed through X-ray diffraction (XRD, PANalytical, Emprean), field-emission scanning electron microscopy (FE-SEM, JEOL JMS-7000F), high-resolution transmission electron microscopy (HR-TEM, JEOL, ARM-200F), thermogravimetric analysis (TGA), and X-ray photoelectron spectroscopy (XPS, Thermo-Scientific, K alpha). Energy-dispersive X-ray spectroscopy (EDX) was conducted using transmission electron microscopy (TEM) at an acceleration voltage of $200 \mathrm{kV}$. The nitrogen adsorption-desorption isotherms were measured using the Brunauer-Emmett-Teller (BET) apparatus, and the Barrett-Joyner-Halenda (BJH) method was performed via the Micrometics, TriSta II 3020 to estimate the specific surface area (SSA), pore size distribution, and total pore volume.

\section{Electrochemical measurements}


The 2032-type coin cells were assembled in an argon-filled glovebox using sulfur cathodes and metallic lithium as an anode with PP (Celgard 2400), NG/PP, or LDHQDs/NG/PP used as the separators. The electrolyte was composed of $1.0 \mathrm{M}$ lithium bis (trifluoromethanesulfonyl) imide (LiTFSI) in a mixture of 1,3-dioxolane (DOL) and dimethoxymethane (DME) $(1: 1, \mathrm{v} / \mathrm{v})$ with $1 \mathrm{wt} \% \mathrm{LiNO}_{3}$. The electrolyte/sulfur ratio used in the coin cell was 15:1 ( $\mu \mathrm{L}: \mathrm{mg})$. The cells were assembled in an argon-filled glovebox with moisture and oxygen concentrations below $1 \mathrm{ppm}$. The galvanostatic charge-discharge tests were conducted in a voltage window of $1.7-2.8 \mathrm{~V}$ on a Maccor instrument (Series 400 automated test system, 1C $=1675 \mathrm{mAh} \mathrm{g}^{-1}$ ). The cyclic voltammetry $(\mathrm{CV})$ curves of the batteries were tested using a Bio-Logic (VMP3) workstation with scan rates varying between 0.1 and $0.4 \mathrm{mV} \mathrm{s}^{-1}$. The electrochemical impedance spectra (EIS) were recorded at an amplitude of $5 \mathrm{mV}$ within the frequency range of $100 \mathrm{kHz}-0.01 \mathrm{~Hz}$.

\section{Absorption test of lithium polysulfide}

To carry out the visualized adsorption test, a $\mathrm{Li}_{2} \mathrm{~S}_{6}$ solution was prepared by mixing $\mathrm{Li}_{2} \mathrm{~S}$ and sulfur at a molar ratio of 1:5 dissolved in DME/DOL (1:1 by volume) followed by vigorous magnetic stirring at $50{ }^{\circ} \mathrm{C}$. The solution was then diluted to $5 \mathrm{mM}$ and used for the adsorption test. PP, NG/PP, and LDH-QDs/NG separators were placed between a vial filled with a reddish-brown $\mathrm{Li}_{2} \mathrm{~S}_{6}$ solution and a perforated lid. The solution was then placed in a vial filled with empty electrolyte. The color of the electrolyte outside the vial was seen as an indicator of the $\mathrm{Li}_{2} \mathrm{~S}_{6}$ solution permeation.

\section{The test of ionic conductivity}


Each of the separators was placed between two stainless steel electrodes and several drops of electrolyte was added to the LSBs sealed in the coin cells. The ionic conductivities of the PP, NG/PP, and LDH-QDs/NG separators were calculated from the electrochemical impedance spectroscopy (EIS) using an electrochemical workstation. ${ }^{1}$ The formula used for calculating the ionic conductivity is

$$
\sigma=\mathrm{L} \div\left(R_{b} \times A\right)
$$

where $\sigma$ is the ionic conductivity, $\mathrm{L}$ is the thickness of the separators, $\mathrm{R}_{\mathrm{b}}$ is the electronic resistance, and A is the area of the stainless-steel electrodes.

Taking the LDH-QDs/NG/PP separator as an example, herein, the parameters of $\mathrm{L}, \mathrm{R}_{\mathrm{b}}$, and $\mathrm{A}$ are $42 \mu \mathrm{m}, 0.783 \Omega$, and $2.01 \mathrm{~cm}^{2}$, respectively. In this case, the as-calculated $\sigma$ for the LDH-QDs/NG/PP separator is $2.67 \times 10^{-3} \mathrm{~S} \mathrm{~cm}^{-1}$. The ionic conductivities of the NG/PP and PP can be obtained following the same calculation process.

\section{Kinetic investigation of polysulfide conversion}

To assemble the symmetric cells, LDH-QDs/NG was coated on an aluminum plate and used as electrodes, which were sandwiched with PP separator in the middle. For the electrolyte, a solution of $1.0 \mathrm{~mol} \mathrm{~L}^{-1}$ LiTFSI was dissolved in a mixture of DOL/DME $(1: 1 \mathrm{v} / \mathrm{v})$ containing $0.25 \mathrm{~mol} \mathrm{~L}^{-1} \mathrm{Li}_{2} \mathrm{~S}_{6}$. The CV curves of the symmetric cells were obtained using an electrochemical workstation at a scan rate of $50 \mathrm{mV} \mathrm{s}^{-1}$. For comparison, NG was also tested following the same processes.

\section{Testing the nucleation of $\mathrm{Li}_{2} \mathrm{~S}$}

The nucleation of $\mathrm{Li}_{2} \mathrm{~S}$ on different surfaces was tested within 2032 coin cells, the assembly process is the same as the polysulfide conversion test. ${ }^{2}$ Lithium foil was used 
as the counter electrode and a Celgard 2400 membrane as separator. The electrolyte used in these cells was $1.0 \mathrm{~mol} \mathrm{~L}^{-1}$ LiTFSI dissolved in DOL and DME containing 0.25 mol L-1 $\mathrm{Li}_{2} \mathrm{~S}_{8}$. The cells were discharged galvanostatically at a current of $500 \mathrm{~mA} \mathrm{mg}^{-1}$ to $2.06 \mathrm{~V}$, after which the cells were discharged potentiostatically at $2.05 \mathrm{~V}$ for $\mathrm{Li}_{2} \mathrm{~S}$ deposition and growth.

\section{Computational details}

We performed all the density functional theory (DFT) calculations using the Vienna $\mathrm{Ab}$ initio Simulation Package (VASP). ${ }^{3}$ Projector-augmented wave (PAW) pseudopotentials ${ }^{4}$ was applied with a plane-wave basis set as implemented in VASP. Perdew-Burke-Ernzerhof (PBE) parametrization of the generalized gradient approximation $(\mathrm{GGA})^{5}$ was used for the exchange-correlation functional. For DFT calculations, a $3 \times 3 \times 1 \mathrm{k}$-point grid was used to calculate LDH (001) surface and NG. Considering the van der Waals interaction between $\mathrm{Li}_{2} \mathrm{~S}_{6}$ and substrate, DFT-D3 correction method ${ }^{6}$ was employed in this study to obtain a more accurate calculation results. The GGA+U $\operatorname{method}^{7}$ was adopted to address the localization of the d-orbital in Co ions on LDH (001) surface, with a $\mathrm{U}$ value of $5.7 \mathrm{eV}$, as used in a previous study. A kinetic energy cutoff of $500 \mathrm{eV}$ were used in all the calculations, and all the structures were optimized until the force in the unit cell converged to within $0.03 \mathrm{eV} \AA^{-1}$. The $E_{\text {ads }}$ were calculated using the following equation:

$$
E_{\text {ads }}=E_{\text {substrate@Li-S }}-\left(E_{\text {substrate }}+E_{\mathrm{Li}-\mathrm{S}}\right)
$$

where $E_{\text {substrate } @ \text { Li-s }}$ is a total energy of substrate which adsorbed $\mathrm{Li}_{2} \mathrm{~S}_{6}, E_{\text {substrate }}$ is a total energy of pristine substrate, and $E_{\mathrm{Li}-\mathrm{S}}$ is a total energy of $\mathrm{Li}_{2} \mathrm{~S}_{6}$ molecule. 
(A)

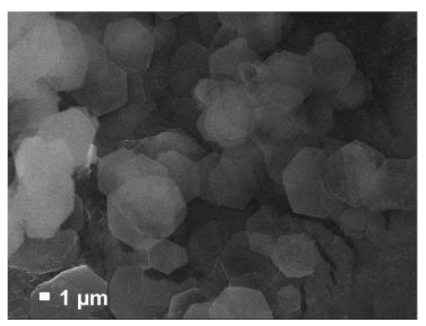

(B)

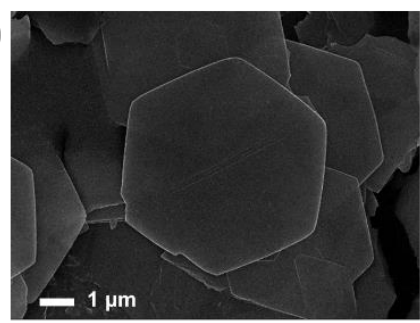

(C)

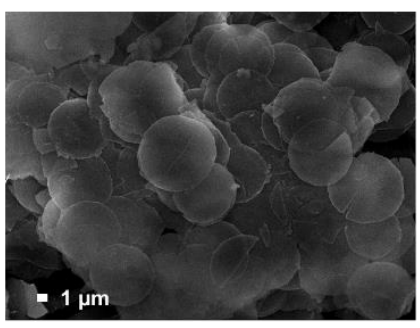

(D)

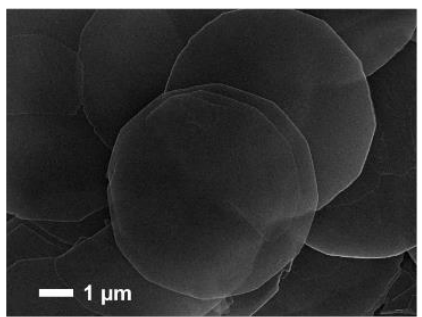

(E)

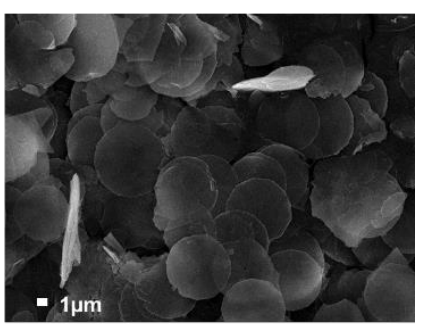

(F)

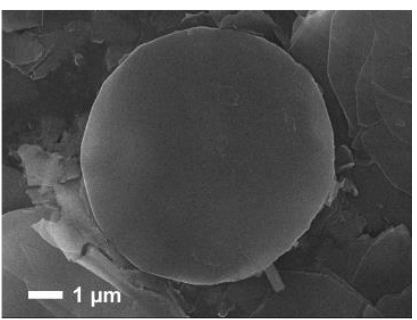

Figure S1. SEM images of (A,B) CoAl-LDH $\left(\mathrm{CO}_{3}{ }^{2-}\right),(\mathrm{C}, \mathrm{D}) \mathrm{CoAl}-\mathrm{LDH}\left(\mathrm{Cl}^{-}\right)$, and (E,F) CoAl-LDH $\left(\mathrm{NO}_{3}^{-}\right)$.
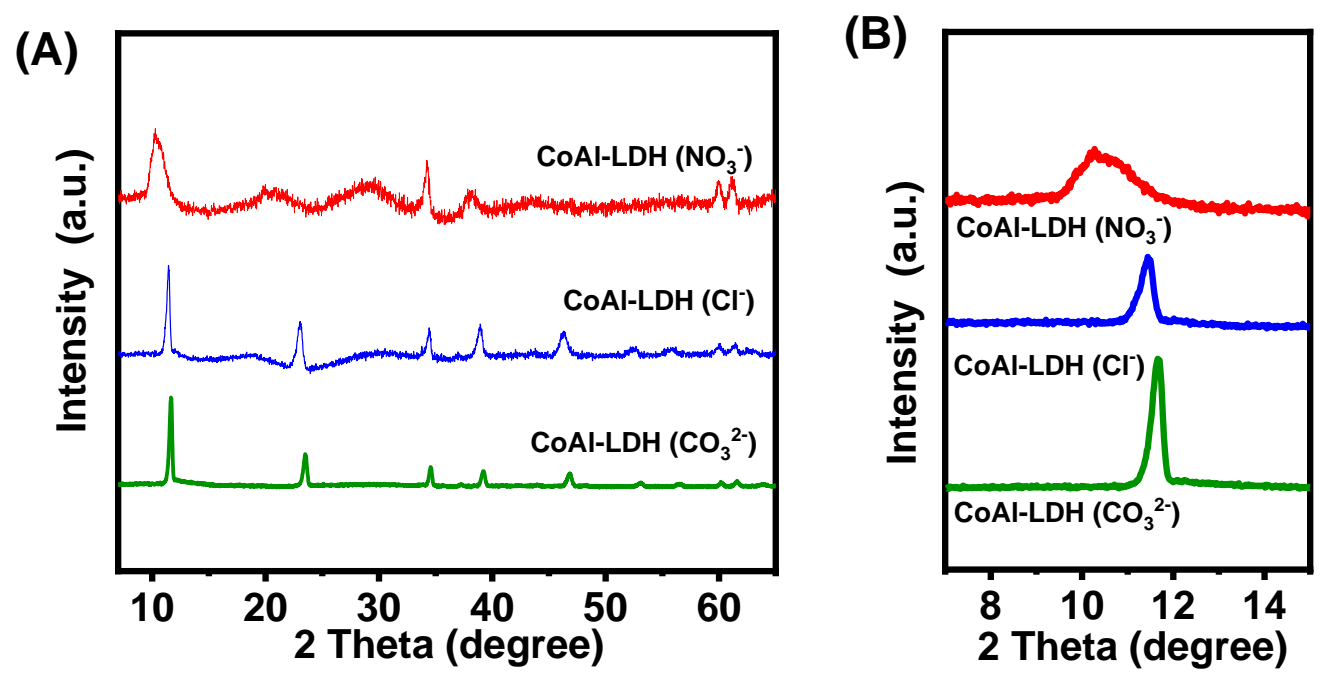

Figure S2. (A) XRD patterns and (B) zoomed XRD patterns from $7^{\circ}$ to $15^{\circ}$ of $\mathrm{LDH}$ $\left(\mathrm{NO}_{3}{ }^{-}\right), \mathrm{LDH}\left(\mathrm{Cl}^{-}\right)$, and $\mathrm{LDH}\left(\mathrm{CO}_{3}{ }^{2-}\right)$. 


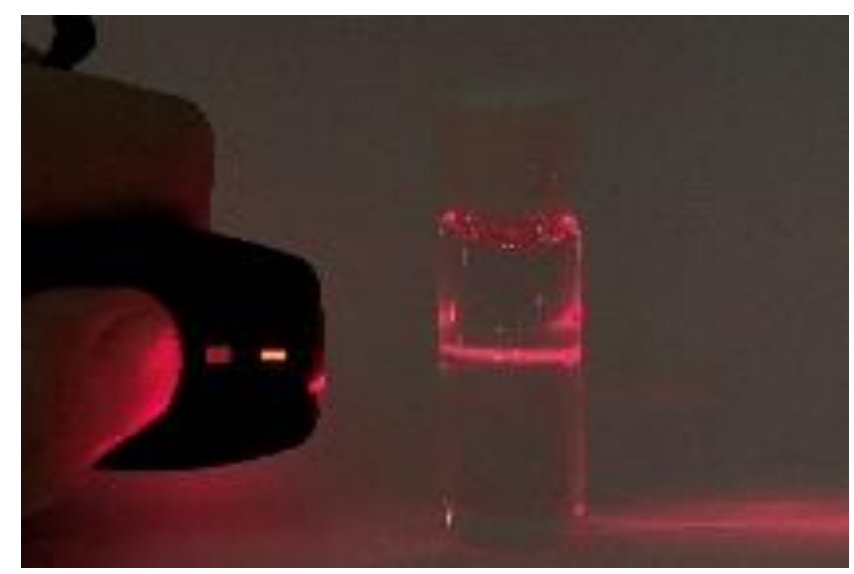

Figure S3. Digital photograph for the Tyndall effect test of the LDH-QDs collide suspension.
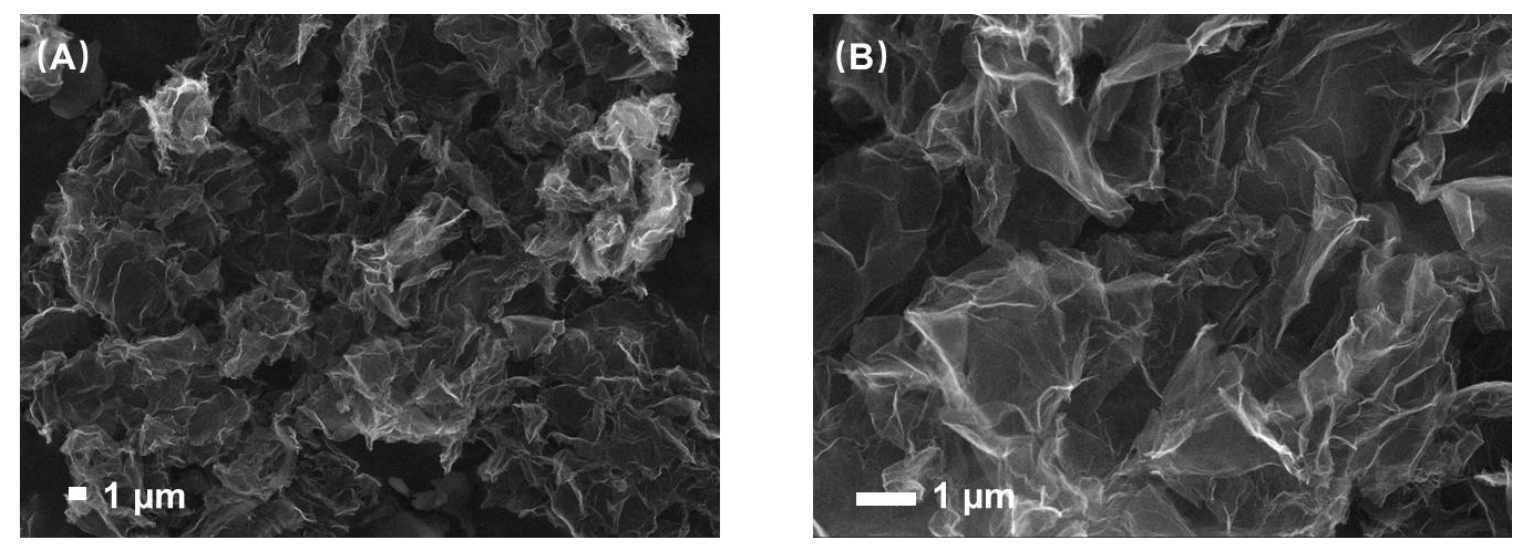

Figure S4. SEM images of NG. 


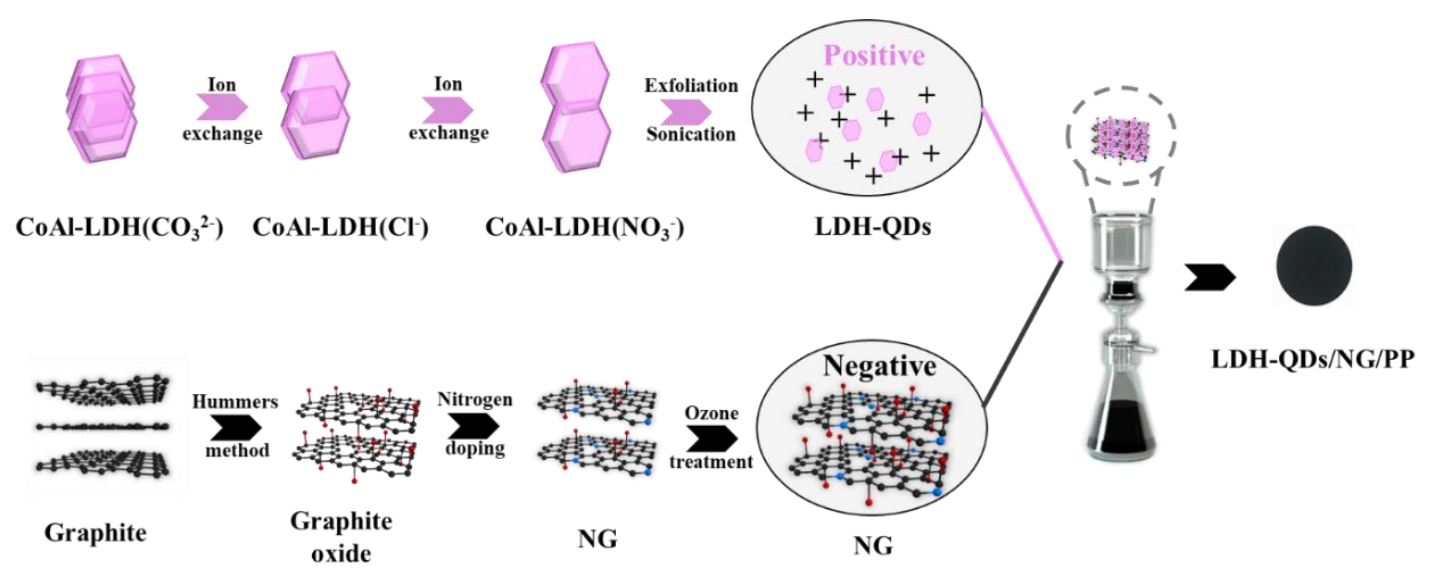

Figure S5. Illustration of a preparation route for the LDH-QDs/NG/PP modified separator.

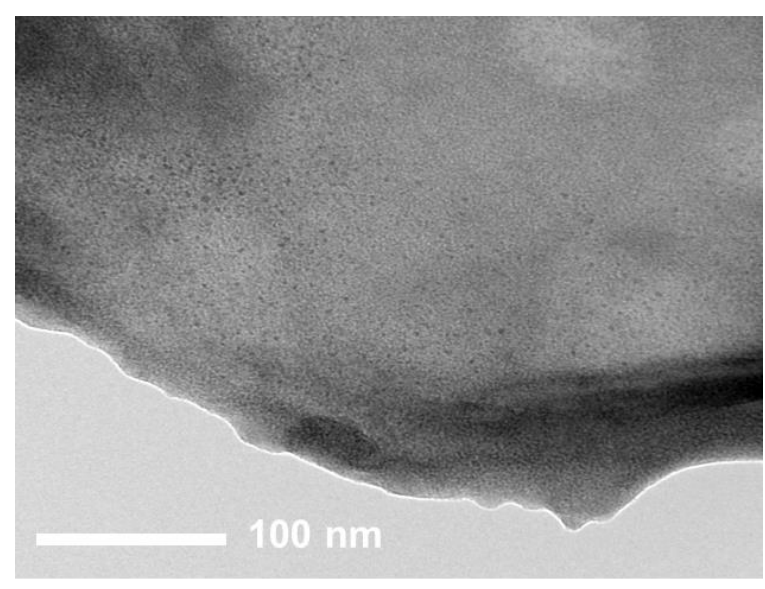

Figure S6. TEM image of LDH-QDs/NG. 
(A)

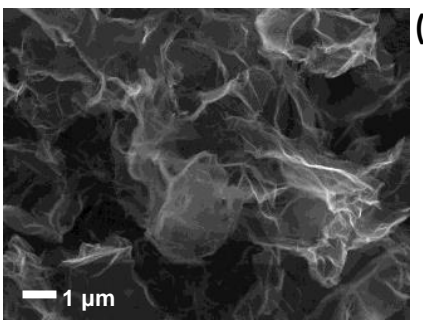

(B)
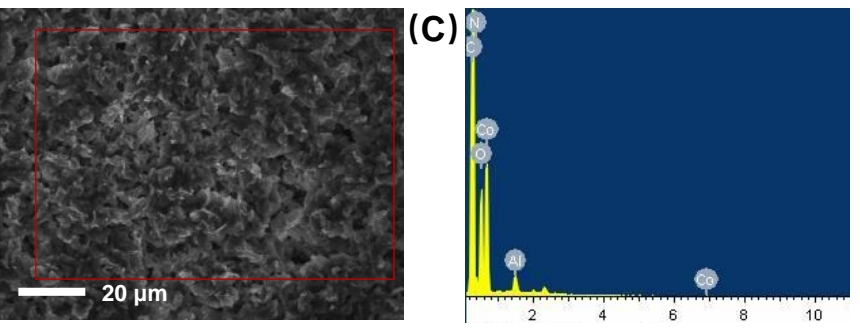

(D)
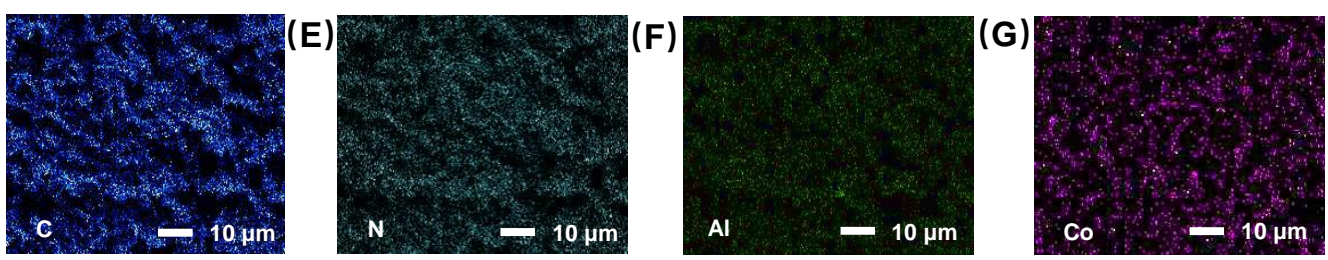

Figure S7. (A,B) SEM images of LDH-QDs/NG. (C) EDS and (D-G) C, N, Al, and Co element mapping images of the LDH-QDs/NG (Note: the red rectangel in B refers to EDX analysis area).

(A)

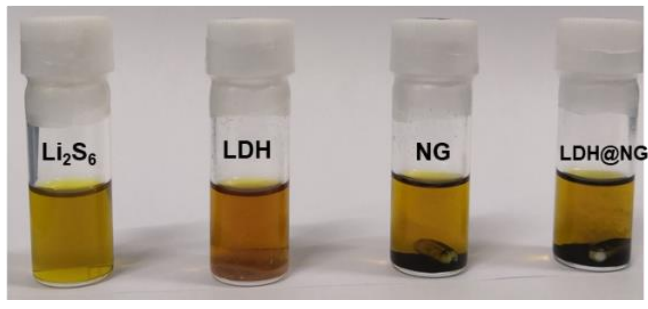

(B)

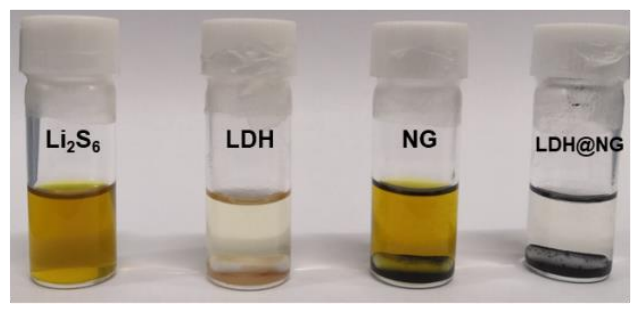

Figure S8. $\mathrm{Li}_{2} \mathrm{~S}_{6}$ absorption experiment of $\mathrm{LDH}, \mathrm{NG}$, and $\mathrm{LDH}-\mathrm{QDs} / \mathrm{NG}$ (A) before and (B) after $\mathrm{Li}_{2} \mathrm{~S}_{6}$ absorption. 


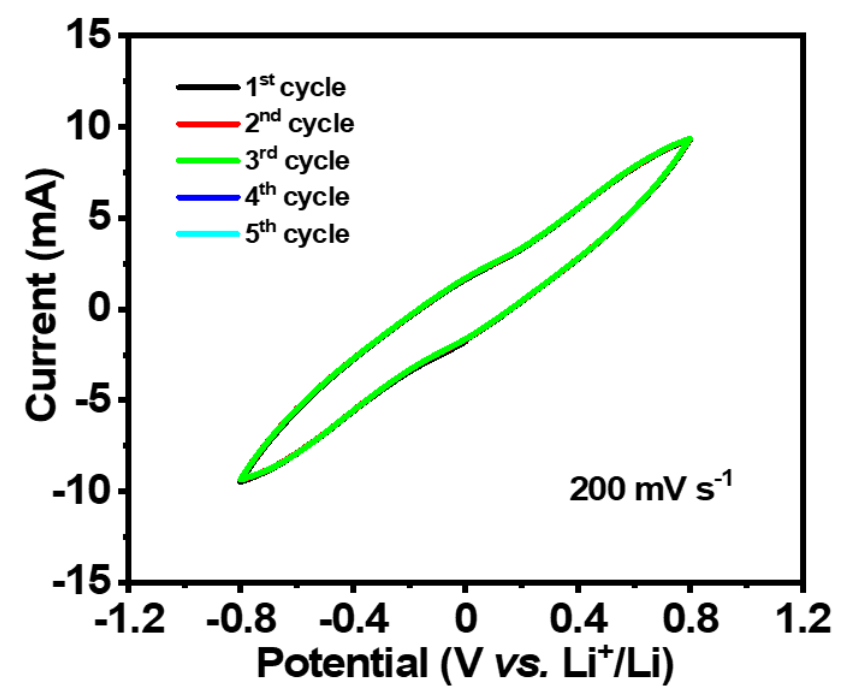

Figure S9. CV curves of symmetric cell with LDH-QDs/NG/PP separator.

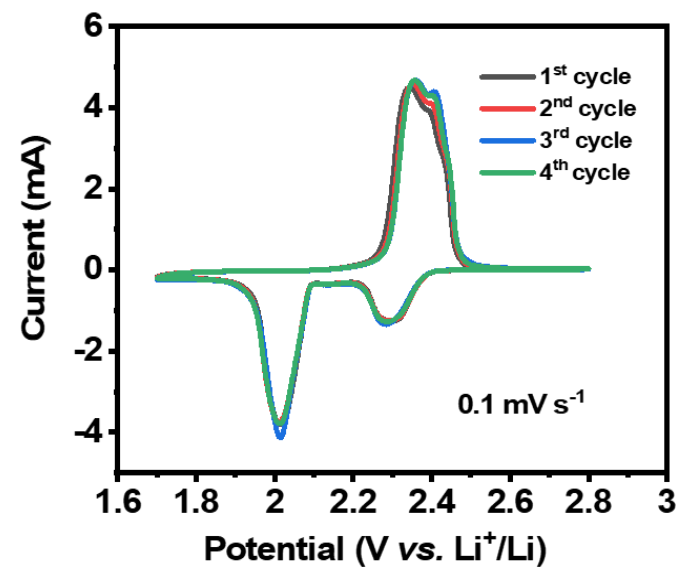

Figure S10. CV curves of LSB with LDH-QDs/NG/PP separator at $0.1 \mathrm{mV} \mathrm{s}^{-1}$. 

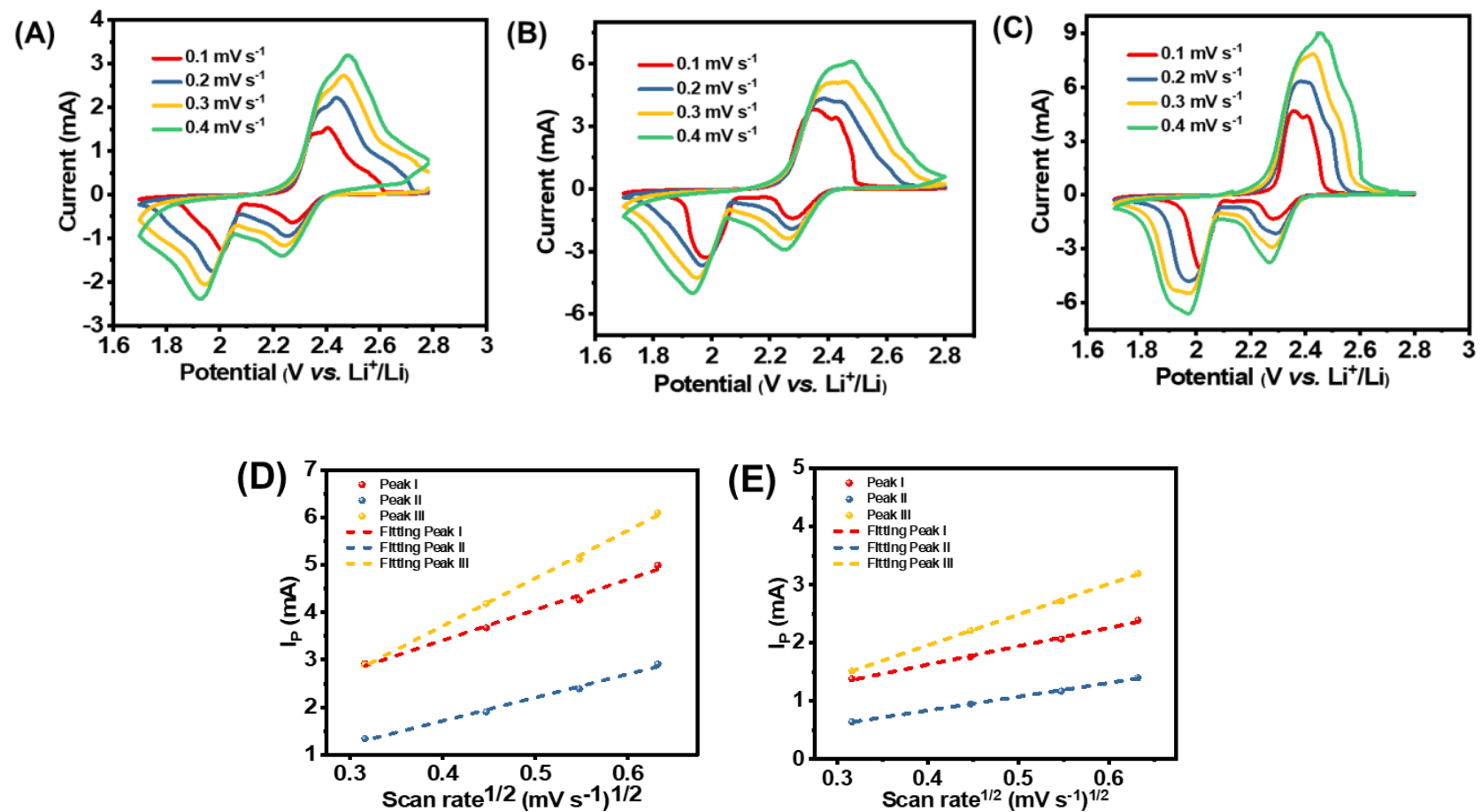

Figure S11. CV curves of the cells with (A) PP, (B) NG/PP, and (C) LDH-QDs/NG/PP separators at different scan rates; and the IP to scan rate relationship of the cells with (D) PP and (E) NG/PP separators.

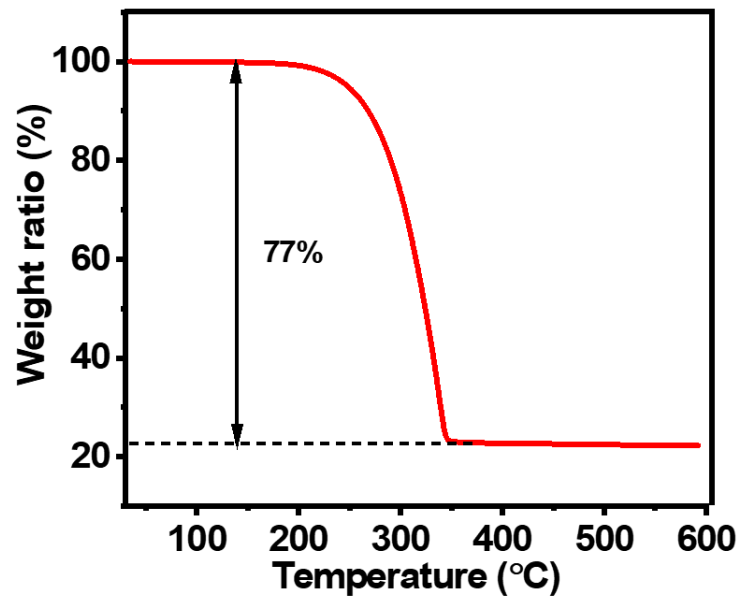

Figure S12. Thermogravimetric analysis curve of MWCNT/S composites. 

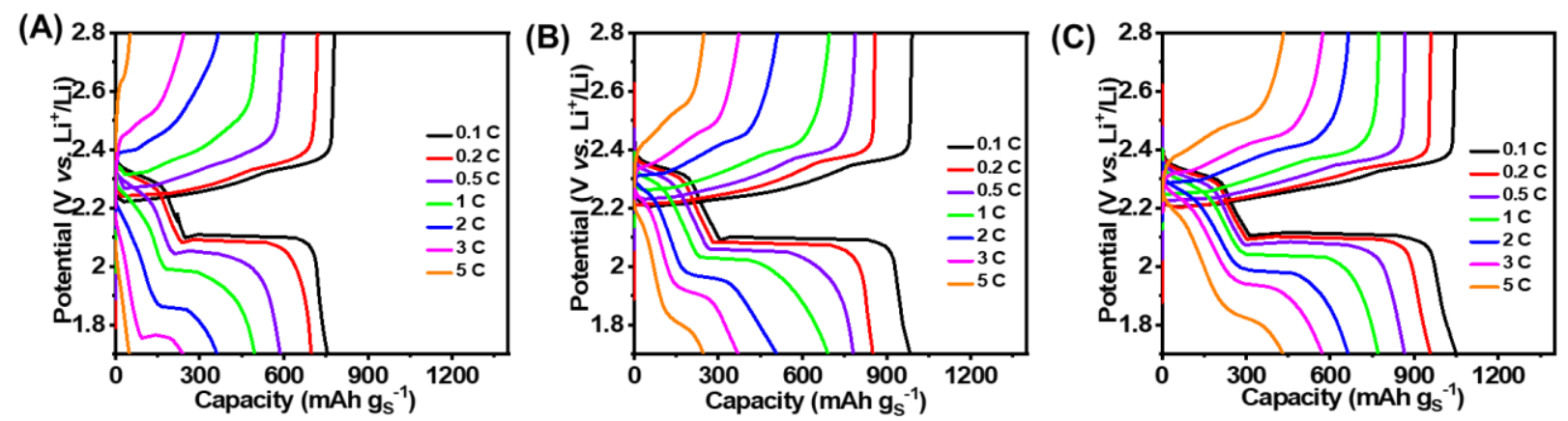

Figure S13. The $5^{\text {th }}$ cycle of GCD curves of the cells with (A) PP, (B) NG/PP, and (C) LDH-QDs/NG/PP separators at different $\mathrm{C}$ rates.

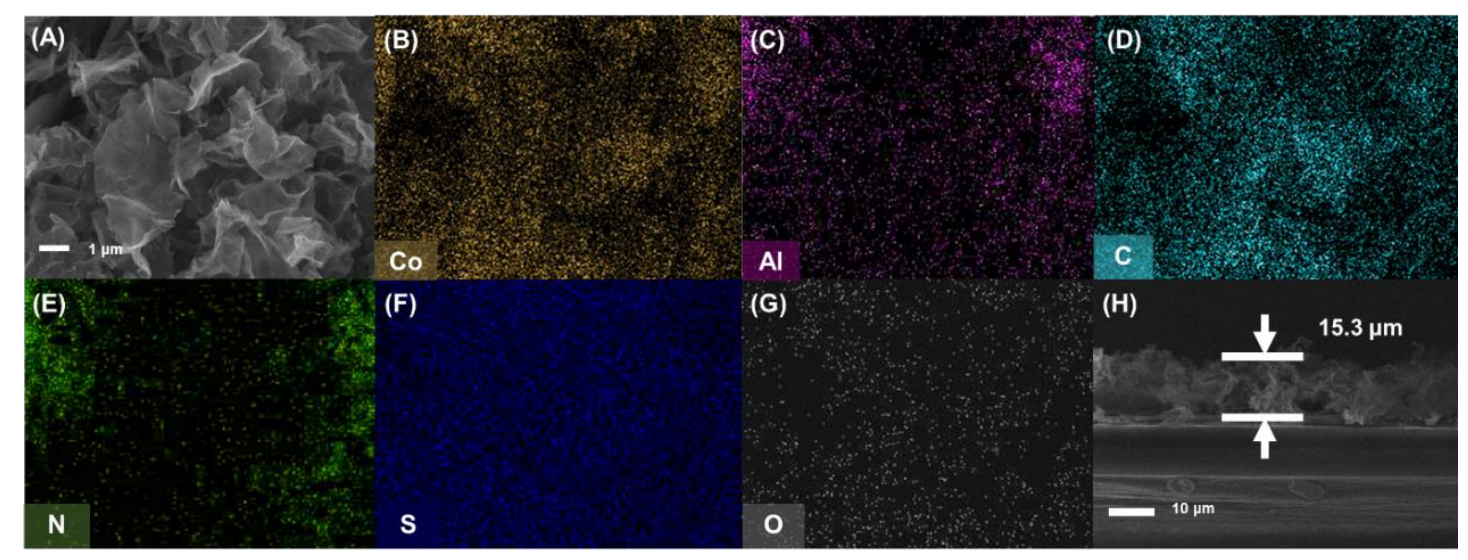

Figure S14. (A) SEM images of the LDH-QDs/NG hybrids after battery cycling. (BG) elemental mapping images of $\mathrm{Co}, \mathrm{Al}, \mathrm{C}, \mathrm{N}, \mathrm{S}$, and $\mathrm{O}$ species for the LDH-QDs/NG hybrids after battery cycling. (H) Cross-sectional SEM image of LDH-QDs/NG/PP separator after battery cycling. 
(A)

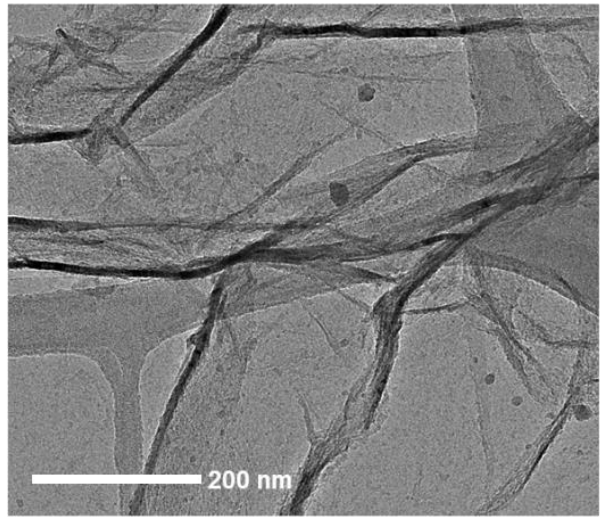

(B)

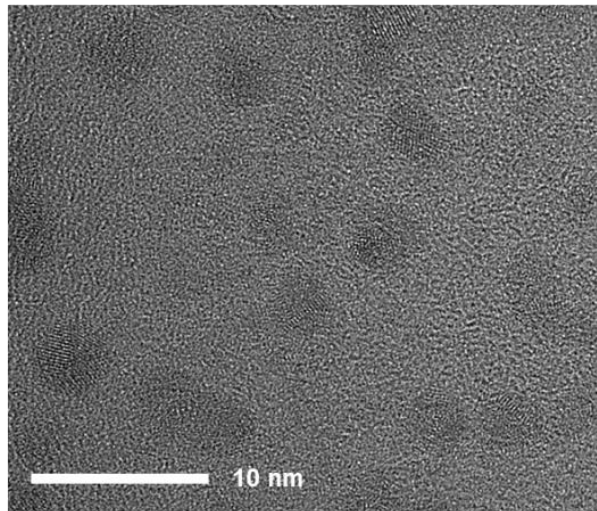

Figure S15. (A)The TEM image and (B) HR-TEM image of the LDH-QDs/NG hybrids after cycling.
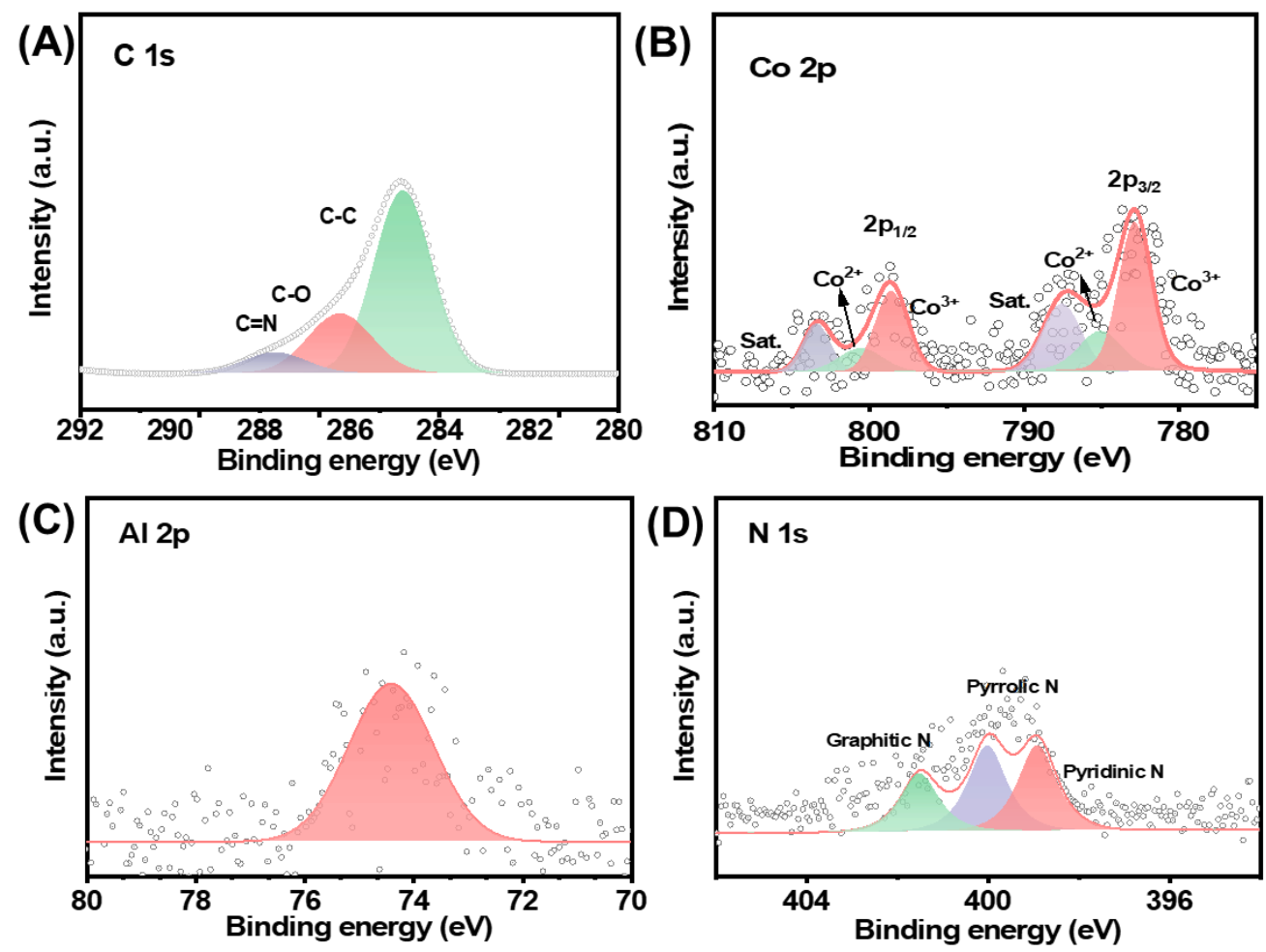

Figure S16. The XPS spectra of LDH-QDs/NG hybrids after cycling (A) C 1s, (B) Co $2 \mathrm{p},(\mathrm{C}) \mathrm{Al} 2 \mathrm{p},(\mathrm{D}) \mathrm{N} 1 \mathrm{~s}$. 

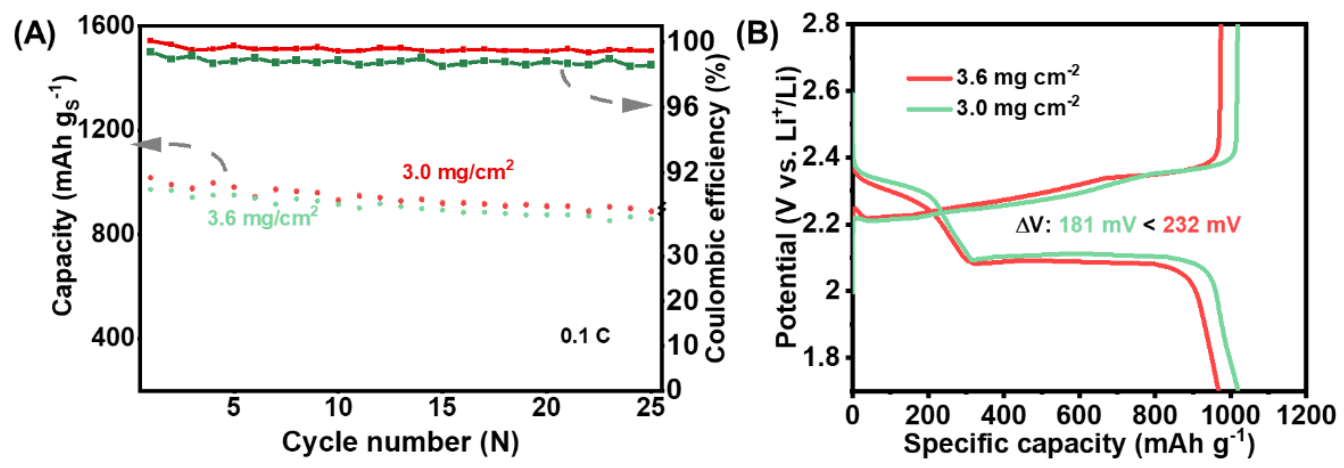

Figure S17. (A) Cycling performance and Coulombic efficiency, and (B) GCD profiles of LSB cells with LDH-QDs/NG/PP separator at $0.1 \mathrm{C}$ (S loading amount of 3.0 and $3.6 \mathrm{mg} \mathrm{cm}^{-2}$ ).

Table S1. Average mesopore size, surface area, pore volume, and isotherm type of NG and LDH-QDs/NG.

\begin{tabular}{ccccc}
\hline Sample & S & Pore Volume & Mesopore size & \\
& $\left(\mathrm{m}^{2} \mathrm{~g}^{-1}\right)$ & $\left(\mathrm{cm}^{3} \mathrm{~g}^{-1}\right)$ & $(\mathrm{nm})$ & Type \\
\hline NG & 223.10 & 51.26 & 25.53 & Type IV \\
LDH-QDs/NG & 242.45 & 55.70 & 21.77 & Type IV \\
\hline
\end{tabular}


Table S2. Comparison of electrochemical performance of this work with previous excellent works involving new separators in lithium-sulfur batteries.

\begin{tabular}{|c|c|c|c|c|c|c|c|c|c|}
\hline Materials & $\begin{array}{c}\text { Mass of } \\
\text { modified } \\
\text { layer } \\
\left.(\mathrm{mg} \mathrm{cm})^{-2}\right)\end{array}$ & $\begin{array}{c}\text { Thickness } \\
\text { of } \\
\text { modified } \\
\text { layer } \\
(\mu \mathrm{m})\end{array}$ & 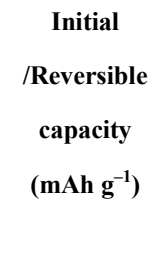 & 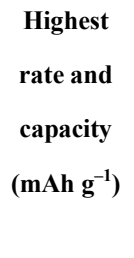 & $\begin{array}{c}\text { Cycle } \\
\text { number }\end{array}$ & $\begin{array}{c}\mathrm{C} \\
\text { rate }\end{array}$ & $\begin{array}{l}\text { Capacity } \\
\left(\mathrm{mAh} \mathrm{g}^{-1}\right)\end{array}$ & $\begin{array}{c}\text { Capacity } \\
\text { decay } \\
\text { rate }(\%)\end{array}$ & Refs. \\
\hline $\begin{array}{c}\text { LDH } \\
\text { QDs@NG }\end{array}$ & 0.3 & 17 & $1228 / 0.1 \mathrm{C}$ & $8 \mathrm{C} / 600$ & 1200 & 1 & 409 & $0.041 \%$ & $\begin{array}{l}\text { This } \\
\text { work }\end{array}$ \\
\hline $\begin{array}{c}\text { Porous } \\
\text { carbon/MCNTs }\end{array}$ & 0.51 & 12 & $905 / 0.2 \mathrm{C}$ & $2 \mathrm{C} / 566$ & 200 & 0.5 & 654 & $0.14 \%$ & 9 \\
\hline Graphene & - & 10 & $1052 / 0.75 \mathrm{~A} / \mathrm{g}$ & $6 \mathrm{C} / 720$ & 300 & 0.9 & 676 & $0.10 \%$ & 10 \\
\hline $\begin{array}{c}\text { Nitrogen doped } \\
\text { graphene } \\
\end{array}$ & - & $25-35$ & - & $0.2 \mathrm{C} / 430$ & 200 & 0.2 & 444 & $0.26 \%$ & 11 \\
\hline $\begin{array}{l}\text { Poly acrylic } \\
\text { acid coated } \\
\text { MWCNTs }\end{array}$ & 0.82 & 7 & $592 / 2 \mathrm{C}$ & $2 \mathrm{C} / 592$ & 200 & 1 & 573 & $0.12 \%$ & 12 \\
\hline $\begin{array}{c}\mathrm{MnO} / \text { Carbon } \\
\text { spheres }\end{array}$ & 0.46 & 14 & $800.2 / 1 \mathrm{C}$ & $2 \mathrm{C} / 537$ & 100 & 1 & 642.7 & $0.2 \%$ & 13 \\
\hline $2 \mathrm{D} \mathrm{ZnCo}_{2} \mathrm{O}_{4}$ & 0.2 & 10 & $1292 / 0.1 \mathrm{C}$ & $10 \mathrm{C} / 323$ & 800 & 1 & 806 & $0.02 \%$ & 14 \\
\hline $\mathrm{CeO}_{2} / \mathrm{RGO}$ & - & 15 & $1136 / 0.1 \mathrm{C}$ & $1 \mathrm{C} /-$ & 100 & 1 & - & - & 15 \\
\hline $\mathrm{rGO} @ \mathrm{MoS}_{2}$ & 0.24 & 8 & $1122 / 0.2 \mathrm{C}$ & $2 \mathrm{C} / 615$ & 200 & 0.2 & 664 & $0.20 \%$ & 16 \\
\hline $\mathrm{Co}_{9} \mathrm{~S}_{8-\mathrm{x}} / \mathrm{CNT}$ & - & 5 & $1273 / 0.3 \mathrm{C}$ & $4 \mathrm{C} / 790$ & 1000 & 0.3 & 648 & $0.049 \%$ & 17 \\
\hline $\mathrm{LDH} / \mathrm{GO}$ & - & - & $1200 / 0.1 \mathrm{C}$ & $1092 / 0.2 \mathrm{C}$ & 500 & 0.2 & 623 & $0.08 \%$ & 18 \\
\hline $\begin{array}{c}\text { SC-Co single } \\
\text { atoms }\end{array}$ & 0.3 & - & $1130 / 0.5 \mathrm{C}$ & $3 \mathrm{C} / 860$ & 300 & 0.5 & 837 & $0.086 \%$ & 19 \\
\hline
\end{tabular}

Table S3. Calculated $\mathrm{Li}_{2} \mathrm{~S}_{6}$-adsorption energy of LDH and NG.

\begin{tabular}{|c|c|}
\hline Sample & Adsorption Energy $\left(E_{a}\right)$ \\
\hline $\mathrm{LDH}_{\mathrm{Li}} \mathrm{Li}_{6}$ & $-2.31 \mathrm{eV}$ \\
\hline 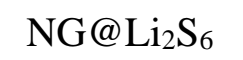 & $-1.91 \mathrm{eV}$ \\
\hline
\end{tabular}




\section{References}

(1) Ghazi, Z. A.; He, X.; Khattak, A. M.; Khan, N. A.; Liang, B.; Iqbal, Z.; Wang, J.; Sin, H.; Li, L.; Tang, Z., $\mathrm{MoS}_{2} /$ Celgard Separator as Efficient Polysulfide Barrier for Long-Life Lithium-Sulfur Batteries. Adv. Mater. 2017, 29, 1606817.

(2) Kong, L.; Chen, J. X.; Peng, H. J.; Huang, J. Q.; Zhu, W.; Jin, Q.; Li, B. Q.; Zhang, X. T.; Zhang, Q. Current-Density Dependence of $\mathrm{Li}_{2} \mathrm{~S} / \mathrm{Li}_{2} \mathrm{~S}_{2}$ Growth in Lithium-Sulfur Batteries. Energy Environ. Sci. 2019, 12, 2976-2982.

(3) Kresse, G.; Furthmüller, J. Efficiency of Ab-initio Total Energy Calculations for Metals and Semiconductors Using A Plane-Wave Basis Set. Comput. Mater. Sci. 1996, $6,15-50$.

(4) Blöchl, P.E. Projector Augmented-Wave Method. Phys. Rev. B. 1994, 50, $17953-$ 17979.

(5) Perdew, J.P.; Burke, K.; Ernzerhof, M. Generalized Gradient Approximation Made Simple. Phys. Rev. Lett. 1996, 77, 3865-3868.

(6) Grimme, S.; Antony, J.; Ehrlich, S.; Krieg, H. A Consistent And Accurate Ab Initio Parametrization of Density Functional Dispersion Ccorrection (DFT-D) for the 94 Elements H-Pu. J. Chem. Phys. 2010, 132,154104.

(7) Anisimov, V.I.; Aryasetiawan, F.; Lichtenstein, A.I. First-Principles Calculations of the Electronic Structure And Spectra of Strongly Correlated Systems: the LDA + U Method. J. Phys. Condens. Matter. 1997, 9, 767-808.

(8) Seo, D.-H.; Gwon, H.; Kim, S.-W.; Kim, J.; Kang, K. Multicomponent Olivine Cathode for Lithium Rechargeable Batteries: A First-Principles Study. Chem. 
Mater. 2010, 22, 518-523.

(9) Tan, L.; Li, X.; Wang, Z.; Guo, H.; Wang, J.; An, L. Multifunctional Separator with Porous Carbon/Multi-walled Carbon Nanotube Coating for Advanced Lithium-Sulfur Batteries. ChemElectroChem. 2018, 5, 71-77.

(10)Zhou, G.; Pei, S.; Li, L.; Wang, D. W.; Wang, S.; Huang, K.; Yin, L. C.; Li, F.; Cheng, H. M. A Graphene-Pure-Sulfur Sandwich Structure for Ultrafast, Long-Life Lithium-Sulfur Batteries. Adv. Mater. 2014, 26, 625-631.

(11)Han, P.; Manthiram, A. Boron-and Nitrogen-Doped Reduced Graphene Oxide Coated Separators for High-Performance Li-S Batteries. J. Power Sources. 2017, 369, 87-94.

(12)Kim, J. H.; Seo, J.; Choi, J.; Shin, D.; Carter, M.; Jeon, Y.; Wang, C.; Hu, L.; Paik, U. Synergistic Ultrathin Functional Polymer-Coated Carbon Nanotube Interlayer for High Performance Lithium-Sulfur Batteries. ACS Appl. Mater. Interfaces. 2016, 8, 20092 20099

(13)Feng, G.; Liu, X.; Wu, Z.; Chen, Y.; Yang, Z.; Wu, C.; Guo, X.; Zhong, B.; Xiang, W.; Li, J. Enhancing Performance of Li-S Batteries by Coating Separator with MnO@YeastDerived Carbon Spheres. J. Alloys Compd. 2020, 817,152723.

(14) Yeon, J. S.; Park, T. H.; Ko, Y. H.; Sivakumar, P.; Kim, J. S.; Kim, Y.; Park, H. S. 2D Spinel $\mathrm{ZnCo}_{2} \mathrm{O}_{4}$ Microsheet-Coated Functional Separator for Promoted Redox Kinetics and Inhibited Polysulfide Dissolution. J. Energy Chem. 2021, 55, 468-475.

(15)Wang, S.; Gao, F.; Zhao, Y.; Liu, N.; Tan, T.; Wang, X. Two-Dimensional $\mathrm{CeO}_{2} / \mathrm{RGO}$ Composite-Modified Separator for Lithium/Sulfur Batteries. Nanoscale Res. Lett. 2018, 13, 377. 
(16)Tan, L.; Li, X.; Wang, Z.; Guo, H.; Wang, J. Lightweight Reduced Graphene Oxide@MoS Interlayer as Polysulfide Barrier for High-Performance Lithium-Sulfur Batteries. ACS Appl. Mater. Interfaces 2018, 10, 3707-3713.

(17)Lin, H.; Zhang, S.; Zhang, T.; Gao, S.; Ye, H.; Yao, Q.; Zheng, G. W.; Lee, J. Y. A cathodeIntegrated Sulfur-Deficient $\mathrm{Co}_{9} \mathrm{~S}_{8}$ Catalytic Interlayer for The Reutilization of "Lost" Polysulfides in Lithium-Sulfur Batteries. ACS Nano. 2019, 13, 7073-7082.

(18)Cui, J.; Li, Z.; Li, J.; Li, S.; Liu, J.; Shao, M.; Wei, M. An Atomic-Confined-Space Separator for High Performance Lithium-Sulfur Batteries. J. Mater. Chem. A. 2020, 8,1896-1903.

(19)Xie, J.; Li, B. Q.; Peng, H. J.; Song, Y. W.; Zhao, M.; Chen, X.; Zhang, Q.; Huang, J. Q. Implanting Atomic Cobalt within Mesoporous Carbon toward Highly Stable LithiumSulfur Batteries. Adv. Mater. 2019, 43, 1903813. 